CASSOWARY volume 2 (1): 30 - 48

ISSN : 2614-8900

E-ISSN : 2622-6545

CProgram Pascasarjana Universitas Papua, https://pasca.unipa.ac.id/

\title{
Dampak alih fungsi hutan mangrove terhadap ekonomi masyarakat di Telaga Wasti Sowi IV Manokwari Papua Barat
}

\author{
Impacts of Changing Functions of Mangrove Forests on Community Economy in Telaga \\ Wasti Sowi IV Manokwari, West Papua
}

Yohan F. Rumwaropen, Bambang Nugroho dan Anton Sineri

Program Studi S2 Ilmu Lingkungan, Program Pascasarjana, Universitas Papua, Jalan Gunung Salju, Amban, Manokwari 98314 Papua Barat Indonesia

*Email: yohanfredrum@gmail.com

\begin{abstract}
Mangrove forest is a vegetation that grows in the estuary beaches and who has the function of ecological, biological, economic and social culture, but now its existence has been degraded by the use of a less appropriate or changing function. Research on the structure of mangrove forest vegetation in the Wasti Bay Sowi IV Manokwari District of Southern District Manokwari conducted in April 2018 with the aim to determine the structure of mangrove forest vegetation and utilization. The method used in this research is the approach of ecological (biological) and anthropological approach. From the analysis of vegetation, found as many as 8 species of mangrove plants. Rhizophora apiculata is the dominant species on the level of a tree with a Density Value of 784.66 Individuals/Ha with an Important Value Index (IVI) 50.06 followed Rhizophora mucronata with a Density Value of 770.34 Individuals/Ha with the Important Value Index (IVI) 41.01. At the level of belta Rhizophora mucronata is the dominant species with a Density Value of 385.66 Individuals/Ha with the Important Value Index (IVI) 45.13 then Rhizophora apiculata with a Density Value of 263.33 Individuals/Ha with the Important Value Index (IVI) 40.22. At the seedling stage Rhizophora mucronata a dominant species with a Density Value of 760.00 Individuals/Ha with the Important Value Index (IVI) 45.42 and Rhizophora apiculata had Density Value of 681.66 Individuals/Ha with the Important Value Index (IVI) 41.04. Based on interviews of 8 mangrove species found in the observation plot, 3 species used as building material, 6 species as a source of firewood, 3 species as drugs and 5 species for other purposes.
\end{abstract}

Keywords: Mangrove Forests, Wasti Bay Sowi IV.

ABSTRAK: Ekosistem hutan mangrove merupakan vegetasi yang tumbuh di lingkungan estuari pantai dan memiliki fungsi ekologi, biologi, ekonomi dan sosial budaya, saat ini telah mengalami degradasi akibat pemanfaatan yang kurang tepat. Penelitian ini dilakukan pada bulan Juli 2018 dengan tujuan untuk mengetahui struktur vegetasi hutan mangrove dan pemanfaatannya. Metode yang digunakan adalah pendekatan ekologi dan antropologi. Dari hasil analisis vegetasi, ditemukan 8 jenis tumbuhan mangrove. Rhizophora apiculata merupakan jenis yang dominan pada tingkat pohon dengan $\mathrm{NK}=784.66$ individu/ha dan $\mathrm{INP}=50.06$ kemudian diikuti Rhizophora 
mucronata dengan $\mathrm{NK}=770.34$ individu/ha dan $\mathrm{NIP}=41.01$. Pada tingkat belta Rhizophora mucronata merupakan jenis yang dominan dengan $\mathrm{NK}=385.66$ individu/ha dan INP=45.13 kemudian Rhizophora apiculata dengan $\mathrm{NK}=263.33$ individu/ha dan $\mathrm{INP}=40.22$. Pada tingkat semai Rhizophora mucronata merupakan jenis dominan dengan $\mathrm{NK}=760.00$ individu/ha dan $\mathrm{INP}=45.42$ dan Rhizophora apiculata dengan $\mathrm{NK}=681.66$ individu/ha dan $\mathrm{INP}=41.04$. Berdasarkan hasil wawancara dari 8 jenis tumbuhan mangrove yang ditemukan dalam plot pengamatan, 3 jenis dimanfaatkan sebagai bahan bangunan, 6 jenis sebagai sumber kayu bakar, 3 jenis sebagai obat-obatan dan 5 jenis untuk keperluan lainnya.

Kata kunci: Hutan Mangrove, Telaga Wasti Sowi IV.

\section{PENDAHULUAN}

Indonesia sebagai daerah tropis mempunyai keanekaragaman hayati tinggi, baik di darat maupun di laut khususnya di wilayah pesisir. Tingginya keanekaragaman hayati tersebut tidak lepas dari kondisi geofisik dan letak geografis perairan Indonesia (Warpur, 2016; Efriyeldi dan Zulkifli, 2012; Dahuri, et al., 2004; Bengen, 2004; Supriharyono, 2002; Kaswadji, 2001). Salah satu unsur keanekaragaman hayati wilayah pesisir dan laut adalah ekosistem hutan mangrove. Hutan mangrove sebagai suatu kelompok tumbuhan yang terdiri atas berbagai macam jenis dari suku yang berbeda, namun memiliki daya adaptasi, morfologi dan fisiologi yang sama terhadap habitat yang selalu dipengaruhi oleh pasang surut air laut (Anugra, et al., 2014; Kordi, 2012; Saparinto, 2007).

Vegetasi hutan mangrove di Indonesia memiliki jumlah jenis tercatat sebanyak 202 jenis, yang terdiri dari 89 jenis pohon, 5 jenis palem, 14 jenis liana, 44 spesies epifit dan 1 jenis sikas (Tuwo, 2011; Matan, et al., 2010). Namun demikian hanya terdapat kurang lebih 47 jenis tumbuhan spesifik hutan mangrove. Paling tidak di dalam hutan mangrove terdapat salah satu jenis tumbuhan sejati penting (dominan) yang termasuk ke dalam 4 famili, yaitu: 1) Rhizophoraceae (Rhizophora sp., Bruguiera sp., Ceriops sp.); 2) Sonneratiaceae (Sonneratia sp.); 3) Avicenniaceae (Avicenia sp.); dan 4) Meliaceae (Xylocarpus sp.). Beberapa tipe komunitas dan kekayaan jenis mangrove yang ada di Papua Barat antara lain di Teluk Bintuni ditemukan 13 jenis (Kusmana, 2003). Sedangkan di Kelurahan Andai Distrik Manokwari Selatan Kabupaten Manokwari komposisi jenis mangrove tingkat semai ditemukan sebanyak 31 jenis, yang terdiri dari 19 jenis mangrove sejati dan 12 jenis mangrove ikutan (Matan, et al., 2010; Kusmana, 2002; Marsono, 1980; Sukardjo, 1979). Mangrove sejati, antara lain: Acanthus ilicifolius (semak), Acrostichum aureum (paku-pakuan), Avicennia alba, A. eucalyptifolia, A. lanata, A. marina, A. officinalis, Bruguiera gymnorrhiza, B. parviflora, $B$. sexangula, Camptostemon schultzii, Ceriops tagal, Heritiera littoralis, Rhizophora apiculata, $R$. stylosa, Sonneratia alba, S. caseolaris, Xylocarpus granatum, X. moluccensis. Sedangkan mangrove ikutan, diantaranya: Artocarpus sp., Derris trifoliate (liana), Dolichandrone spathaceae, Hibiscus tiliaceus, Intsia bijuga, Pandanus tectorius (pandan), Pleomele angustifolia (perdu), Premna corymbosa, Pterocarpus indicus, 
Scaevola taccada (perdu), Sophora sp. (perdu), Syzygium anomala. Berdasarkan fakta-fakta tersebut dapat diketahui berbagai keanekaragaman dan distribusi jenis mangrove yang ada di Papua Barat, dimana akan berbeda menurut kondisi wilayah masingmasing daerah yang dipengaruhi oleh faktor-faktor fisik wilayahnya masingmasing.

Ditinjau dari fungsi ekologi, sumberdaya mangrove mempunyai beberapa fungsi yang dilihat dari beberapa aspek antara lain: aspek fisik, kimia dan biologi. Fungsi ini sangat menunjang pemenuhan kebutuhan hidup manusia dan berfungsi sebagai penyangga keseimbangan ekosistem di wilayah pesisir.

Fungsi ekologi ditinjau dari aspek fisik antara lain mampu berperan sebagai penahan abrasi, penahan angin/badai, penahan banjir, sebagai kawasan penyangga proses intrusi/ rembesan air laut ke darat atau sebagai filter air asin menjadi tawar (Saparinto, 2007). Dari aspek kimia, hutan mangrove dapat berfungsi sebagai penyerap bahan pencemar, khususnya bahanbahan organik sebagai sumber energi bagi lingkungan perairan sekitarnya, pensuplai bahan-bahan organik bagi lingkungan perairan, sebagai tempat terjadinya proses daur ulang yang menghasilkan oksigen dan menyerap karbondioksida, sebagai tempat pengolah bahan-bahan limbah industri (Arief, 2003; Nontji, 2002).

Fungsi biologi antara lain sebagai penghasil bahan pelapukan yang merupakan sumber makanan penting bagi invertebrata kecil pemakan bahan pelapukan kemudian berperan sebagai sumber makanan bagi hewan yang lebih besar. Selain itu hutan mangrove juga sangat bermanfaat sebagai kawasan pemijah atau asuhan bagi biota laut yang setelah dewasa akan kembali ke laut, sebagai tempat berlindung, bersarang serta berkembang biak bagi burung dan satwa lain, sebagai habitat alami bagi berbagai jenis biota darat maupun biota laut lainnya (Warpur, 2016; Kustanti, 2011; Rahmawaty, 2006).

Bila dilihat dari aspek sosial ekonominya, hutan mangrove memiliki manfaat yang relatif besar bagi masyarakat, khususnya masyarakat yang tinggal di sekitarnya antara lain hutan mangrove bermanfaat sebagai penyedia keperluan rumah tangga; misalnya sebagai bahan konstruksi bangunan, kayu bakar dan arang, obatobatan, bahan makanan maupun sebagai area pertambakan (Okoseray, et al., 2017; Bengen, 2003). Selain itu mangrove juga berperan dalam keperluan industri, misalnya sebagai bahan baku kertas, penyamak kulit, lemari/furniture dan juga sebagai kayu lapis (Noor, et al., 2006; Satari, et al., 1996). Walaupun hutan mangrove memiliki fungsi ekologi dan manfaat sosial ekonomi yang sangat penting, namun saat ini keberadaannya telah mengalami degradasi akibat pemanfaatan yang kurang tepat dan mengalami perubahan fungsi seperti yang sedang terjadi pada hutan mangrove di Telaga Wasti Sowi IV Kabupaten Manokwari yang memiliki luas areal \pm sekitar 25 ha. Oleh karena itu perlu dilakukan penelitian untuk mengetahui keanekaragaman hayati hutan mangrove sebelum mengalami penurunan jenis akibat terjadinya degradasi. Maka data dan informasi hasil penelitian sangat diperlukan.

\section{METODE PENELITIAN}

\section{Waktu Dan Tempat}

Penelitian ini berlangsung selama bulan April 2018 dengan lokasi sasaran, yaitu Hutan Mangrove Telaga 
Wasti Sowi IV, Distrik Manokwari Selatan, Kabupaten Manokwari - Papua Barat (Gambar 1). Lokasi penelitian ini dipilih karena mayoritas penduduk lokalnya memanfaatkan hutan mangrove di sekitarnya untuk keperluan konsumsi keluarga dan sumber penghasilan. Masyarakat di lokasi tersebut saat ini telah diperhadapkan pada pilihan antara konservasi dan penggunaan lahan yang masif karena pembangunan Kabupaten Manokwari sebagai Ibu Kota Provinsi Papua Barat, maka pembukaan lahan di daratan semakin luas. Hal ini secara langsung maupun tidak langsung berpengaruh terhadap degradasi hutan mangrove.

\section{Alat dan Bahan}

Alat yang digunakan dalam penelitian ini, diantaranya peta administrasi, peta lokasi penelitian dan peta kawasan hutan mangrove Telaga Wasti Sowi IV tahun 2010, 2013 dan tahun 2016, laptob toshiba untuk mengolah data lapangan, Drone dan GPS Garmin 64s untuk menentukan titik koordinat lokasi penelitian, kuisioner sebagai panduan pertanyaan yang diisi oleh orang yang akan diukur, alat tulis menulis (bolpoin dan kertas) untuk mencatat data-data yang diperoleh di lapangan, meteran roll kennedy $100 \mathrm{~m} / 330^{\prime}$ untuk mengukur panjang dan lebar plot, parang untuk merintis jalur pembuatan plot, buku identifikasi mangrove, alat perekam suara pedometer dan kamera digital olympus untuk dokumentasi.

Bahan yang digunakan terdiri dari label untuk memberikan informasi pada sampel, tali rafia untuk membuat plot, botol sebagai tempat menyimpan sampel dan bahan kontak (rokok, siripinang dan kopi-gula) untuk pendekatan pada masyarakat di lokasi penelitian.

\section{Prosedur Penelitian}

Metode yang digunakan dalam penelitian ini adalah dengan menggunakan 2 pendekatan, yaitu: pendekatan ekologi/biologi dan pendekatan antropologi. Pendekatan ekologi dilakukan untuk mengetahui kondisi vegetasi hutan mangrove tingkat pohon dilakukan dengan metode transek kuadrat/ metode jalur, sedangkan penetuan plot (Gambar 2) pengamatan tingkat belta/pancang (anakan pohon) dan semai dilakukan secara random/secara garis berpetak (Warpur, 2016; Anugra, et al., 2014; Toknok, 2012).

Plot pengamatan diletakkan secara acak pada vegetasi yang berbeda, yaitu 2 jalur vegetasi hutan mangrove yang rusak dan 1 jalur vegetasi hutan mangrove yang masih baik sebagai pembanding, penarikan transek/jalur dari arah laut ke darat, sebanyak 3 jalur berbentuk bujur sangkar dengan ukuran $15 \times 15 \mathrm{~m}$ (pohon), $10 \times 10 \mathrm{~m}$ (belta/pancang/anakan pohon) dan 5 x 5 m (semai).

Pengambilan data vegetasi hutan mangrove di Telaga Wasti Sowi IV pada 3 jalur dari tepi pantai sampai darat, yaitu: jalur 1 (pintu masuk perahu) dibuat 6 plot dengan panjang 60 $\mathrm{m}$ dan ekosistem mangrovenya sangat baik, jalur 2 (pintu air) dibuat 5 plot dengan panjang $50 \mathrm{~m}$, lokasi ini terletak di belakang pemukiman warga yang ekosistem mangrovenya cukup baik dan jalur 3 (pemukiman) dibuat 4 plot dengan panjang $40 \mathrm{~m}$, lokasinya terletak dekat pemukiman yang kondisi ekosistem mangrovenya rusak sedang.

Jenis data yang dikumpulkan dalam penelitian ini terdiri atas data primer dan data sekunder. Data primer meliputi pengamatan vegetasi meliputi nama jenis dan kerapatan yang diperoleh melalui secara langsung di lokasi penelitian dengan teknik survei, menggunakan kuisioner dan wawancara 
mendalam serta wawancara tidak terstruktur kepada responden. Sedangkan data sekunder diperoleh dari lembaga swadaya masyarakat dan instansi/dinas yang terkait serta literatur pendukung yang ada kaitannya dengan penelitian.

Selain itu juga dikumpulkan berbagai data penunjang seperti: kondisi fisik wilayah, sejarah, pola penguasaan lahan, program, kebijakan pemerintah, peraturan perundangan dan data sosial ekonomi yang dibutuhkan dalam penelitian ini meliputi: data penduduk dan riwayatnya, tingkat pendidikan, mata pencaharian dan pendapatan penduduk, tingkat pemanfaatan mangrove oleh masyarakat, sarana prasarana serta pandangan masyarakat terhadap pengelolaan mangrove di Telaga Wasti Sowi IV.

Pendekatan

antropologis digunakan untuk menggambarkan bagaimana manfaat ekologi, ekonomi, sosial dan budaya hutan mangrove di Telaga Wasti Sowi IV melalui wawancara. Penilaian secara ekologi dibahas dalam bentuk analisis data dilakukan secara deskripsi kualitatif untuk mengetahui dampak alih fungsi lahan atau pemanfaatan keanekaragaman hayati hutan mangrove serta deskriptif kuantitatif digunakan untuk mengetahui struktur vegetasi hutan mangrove sebagai berikut (Warpur, 2016; Fachrul, 2007).

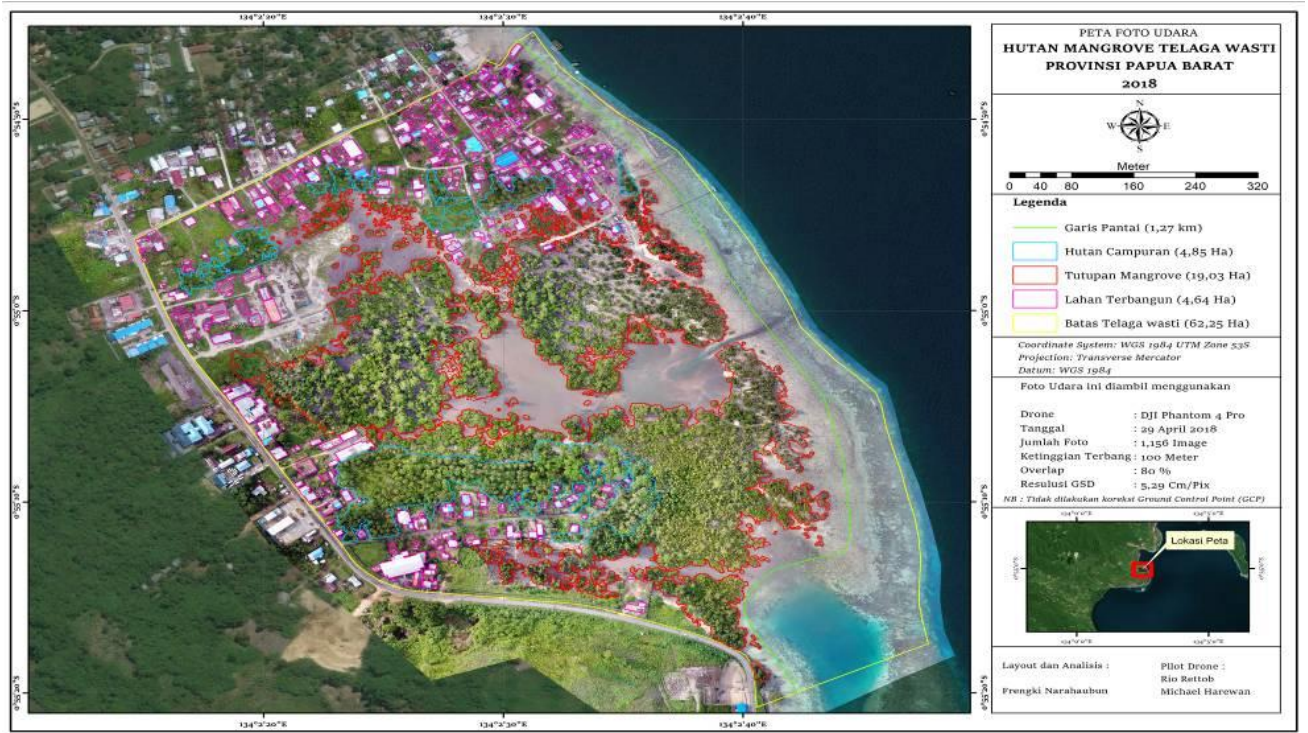

Gambar 1. Peta lokasi penelitian (Sumber: Drone DJI Phantom 4 Pro, 2018)

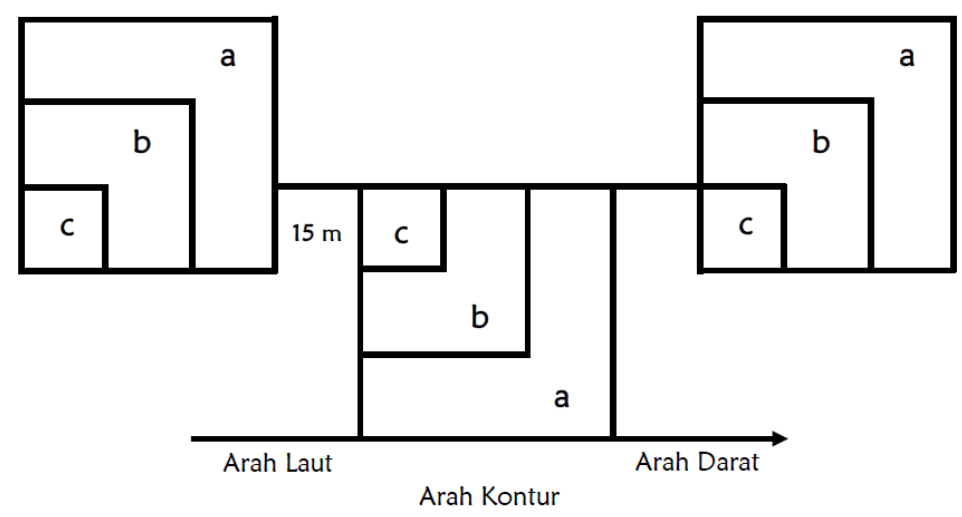

Gambar 2. Plot pengamatan yang dilakukan secara random/secara garis berpetak 


\section{Keterangan:}

a. Petak Sub-plot a, ukuran $15 \times 15 \mathrm{~m}$ untuk analisis tingkat pohon

b. Petak Sub-plot b, ukuran $10 \times 10$ m untuk analisis tingkat belta (anakan pohon)

c. Petak Sub-plot c, ukuran $5 \times 5 \mathrm{~m}$ untuk analisis tingkat semai

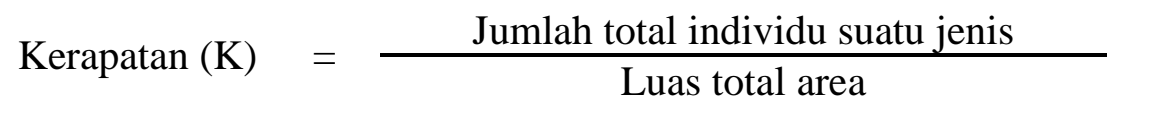

Kerapatan Relatif

(KR)

Kerapatan suatu jenis

Kerapatan individu seluruh jenis X $100 \%$<smiles>C1CCCC1</smiles>

Dominansi $=\frac{\text { Luas basal }}{\text { Luas petak contoh }}$

Dominansi Relatif

(DR)

$$
=\frac{\text { Dominansi suatu jenis }}{\text { Dominansi seluruh jenis }} \times 100 \%
$$

Jumlah petak sampel tempat ditemukan suatu

Frekwensi $=$ jenis

Jumlah total petak sampel yang diamati
Frekwensi Relatif (FR)

$$
=\frac{\text { Jumlah frekwensi suatu jenis }}{\text { Jumlah frekwensi seluruh jenis }} \times 100 \%
$$

Indeks Nilai Penting (INP) pohon dan belta/pancang dihitung dengan menggunakan rumus berikut ini.

$$
\text { Indeks Nilai Penting (INP) }=\mathrm{KR}+\mathrm{DF}+\mathrm{FR}
$$

Sedangkan Indeks Nilai Penting (INP) untuk jenis semai dihitung dengan rumus:

$$
\text { Indeks Nilai Penting (INP) } \quad=\text { KR }+ \text { FR }
$$

Untuk mengetahui tingkat keanekaragaman jenis $\left(\mathrm{H}^{\prime}\right)$, digunakan rumus indeks keanekaragaman berdasarkan Shannon-Wienner (1949) dalam Krebs (1989).

\section{Dimana:}

$$
\mathrm{H}^{\prime}=\underset{\substack{\mathrm{N} \\ \mathrm{i}=1}}{-\sum \mathrm{ni} / \mathrm{Nl} \log \mathrm{ni} / \mathrm{N}}
$$

- $\mathrm{H}^{\prime}$ = Indeks Keanekaragaman Shannon-Wienner

- $n i=$ Jumlah individu dari suatu jenis $\mathrm{i}, \mathrm{i}=1,2,3, \ldots$

- $\mathrm{N}=$ Jumlah total individu seluruh jenis 


\section{HASIL}

\section{Kondisi Hutan Mangrove}

Berdasarkan hasil analisis vegetasi yang telah dilakukan ditemukan 4 famili tumbuhan mangrove yang terdiri dari 8 jenis (Tabel 1).

Tabel 1. Keragaman jenis mangrove di Telaga Wasti Sowi IV

\begin{tabular}{clcl}
\hline No. & \multicolumn{1}{c}{ Famili } & No. & \multicolumn{1}{c}{ Jenis } \\
\hline 1. & Myrsinaceae & 1. & Aegiceras corniculatum \\
2. & Rhizophoraceae & 2. & Bruguiera gymnorrhiza \\
& & 3. & Ceriops decandra \\
& & 4. & Ceriops tagal \\
& & 5. & Rhizophora apiculata \\
3. & Combretaceae & 6. & Rhizophora mucronata \\
4. & Meliaceae & 7. & Lumnitzera littorea \\
\hline
\end{tabular}

Dari 8 jenis tumbuhan mangrove tersebut, jenis Rhizophora apiculata, Rhizophora mucronata dan Bruguiera gymnorrhiza merupakan jenis yang dominan pada vegetasi tingkat pohon, belta/pancang maupun semai (Tabel 2, 3 dan 4) berikut ini.

Tabel 2. Indeks keanekaragaman pada tingkat pohon di Telaga Wasti Sowi IV

\begin{tabular}{llcccccccc}
\hline No. & \multicolumn{1}{c}{ Jenis } & $\mathrm{K}$ & $\mathrm{KR}$ & $\mathrm{F}$ & $\mathrm{FR}$ & $\mathrm{D}$ & $\mathrm{DR}$ & $\mathrm{INP}$ & $\mathrm{H}^{\prime}$ \\
\hline 1. & $\begin{array}{l}\text { Rhizophora } \\
\text { apiculata }\end{array}$ & 784.66 & 17.47 & 0.52 & 15.62 & 20197.54 & 20.22 & 50.06 & 0.20 \\
2. $\begin{array}{l}\text { Rhizophora } \\
\text { mucronata }\end{array}$ & 770.34 & 16.62 & 0.57 & 14.67 & 25157.57 & 17.34 & 41.01 & 0.27 \\
3. & $\begin{array}{l}\text { Bruguiera } \\
\text { gymnorrhiza }\end{array}$ & 625.33 & 14.54 & 0.50 & 13.15 & 10136.18 & 13.62 & 33.02 & 0.26 \\
4. $\begin{array}{l}\text { Ceriops } \\
\text { decandra }\end{array}$ & 416.67 & 11.28 & 0.76 & 12.21 & 11103.22 & 11.24 & 31.31 & 0.15 \\
5. $\begin{array}{l}\text { Ceriops tagal } \\
\text { Aegiceras }\end{array}$ & 487.33 & 11.26 & 0.45 & 12.64 & 5607.41 & 10.03 & 31.12 & 0.13 \\
6. & 158.67 & 12.53 & 0.18 & 10.15 & 1646.25 & 11.64 & 6.21 & 0.08 \\
7. $\begin{array}{l}\text { Lorniculatum } \\
\text { Lumnitzera }\end{array}$ & 113.68 & 11.29 & 0.43 & 11.26 & 11039.74 & 11.52 & 4.12 & 0.06 \\
$\begin{array}{l}\text { littorea } \\
\text { Xilocarpus }\end{array}$ & 108.33 & 5.01 & 0.12 & 10.30 & 5329.37 & 4.39 & 3.15 & 0.04 \\
\hline $\begin{array}{l}\text { moluccensis } \\
\text { J U M L A H }\end{array}$ & 3465.01 & 100.00 & 3.53 & 100.00 & 90217.28 & 100.00 & 200.00 & 1.19 \\
\hline
\end{tabular}

Keterangan: $\mathrm{K}=$ Kerapatan (ind./ha), $\mathrm{KR}=$ Kerapatan Relatif (ind./ha), $\mathrm{F}=$ Frekwensi (\%), FR = Frekwensi Relatif (\%), $\mathrm{D}=$ Dominansi Setiap Spesies $\left(\mathrm{m}^{2} / \mathrm{ha}\right), \mathrm{DR}=$ Dominansi Relatif $\left(\mathrm{m}^{2} / \mathrm{ha}\right)$, INP = Indeks Nilai Penting (\%), $\mathrm{H}^{\prime}=$ Indeks Keanekaragaman $(\%)$

Tabel 3. Indeks keanekaragaman pada tingkat belta/anakan pohon di Telaga Wasti Sowi

\begin{tabular}{llllllllll}
\multicolumn{10}{c}{ IV } \\
\hline No. & Jenis & K & KR & F & FR & D & DR & INP & $\mathrm{H}^{\prime}$ \\
\hline
\end{tabular}




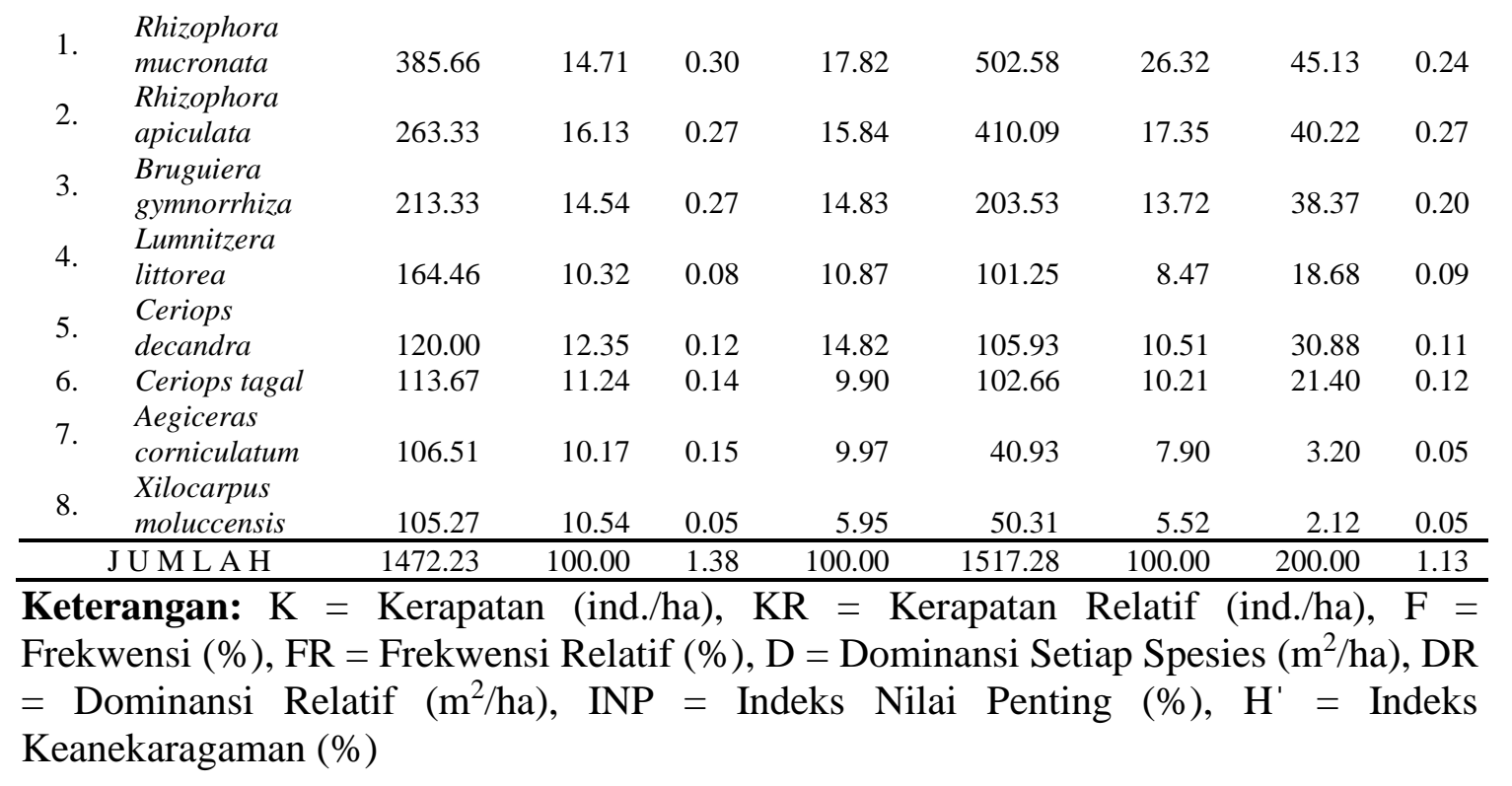

Tabel 4. Indeks keanekaragaman pada tingkat Semai di Telaga Wasti Sowi IV

\begin{tabular}{|c|c|c|c|c|c|c|c|}
\hline No. & Jenis & $\mathrm{K}$ & KR & $\mathrm{F}$ & FR & INP & $\mathrm{H}^{\prime}$ \\
\hline 1. & Rhizophora mucronata & 760.00 & 16.58 & 0.23 & 17.32 & 45.42 & 0.27 \\
\hline 2. & $\begin{array}{l}\text { Rhizophora apiculata } \\
\text { Bruguiera }\end{array}$ & 681.66 & 17.60 & 0.24 & 15.61 & 41.04 & 0.29 \\
\hline 3. & gymnorrhiza & 571.31 & 12.16 & 0.14 & 14.21 & 29.38 & 0.27 \\
\hline 4. & Ceriops decandra & 501.67 & 13.31 & 0.13 & 15.83 & 32.16 & 0.18 \\
\hline 5. & Ceriops tagal & 481.33 & 14.76 & 0.11 & 13.62 & 30.43 & 0.16 \\
\hline 6. & Lumnitzera littorea & 282.33 & 9.23 & 0.05 & 8.20 & 12.41 & 0.01 \\
\hline 7. & $\begin{array}{l}\text { Xilocarpus } \\
\text { moluccensis }\end{array}$ & 281.67 & 8.38 & 0.09 & 5.26 & 6.63 & 0.03 \\
\hline 8. & $\begin{array}{l}\text { Aegiceras } \\
\text { corniculatum }\end{array}$ & 102.17 & 7.98 & 0.04 & 9.95 & 2.53 & 0.04 \\
\hline & Jumlah & 3662.14 & 100.00 & 1.03 & 100.00 & 200.00 & 1.25 \\
\hline
\end{tabular}

Keterangan: $\quad \mathrm{K}=$ Kerapatan (ind./ha), $\mathrm{KR}=$ Kerapatan Relatif (ind./ha), $\mathrm{F}=$ Frekwensi (\%), FR = Frekwensi Relatif (\%), INP = Indeks Nilai Penting (\%), $\mathrm{H}^{\prime}=$ Indeks Keanekaragaman (\%)

\section{Pemanfaatan Hutan Mangrove Oleh Masyarakat Di Telaga Wasti Sowi IV}

Hasil wawancara dengan responden diketahui bahwa aneka ragam hayati hutan mangrove dimanfaatkan penduduk untuk berbagai kegunaan, seperti: pemanfaatan tumbuhan mangrove sebagai bahan konstruksi bangunan, sumber kayu bakar dan arang, sumber bahan pangan, sumber bahan obat-obatan dan keperluan lainnya, seperti: pewarna, alat tarnsportasi dan bahan penunjang rumah tangga. Hal ini diperkuat oleh pendapat Bengen (2003), bahwa manfaat ekonomi yang dapat diperoleh dari hutan mangrove adalah kayu untuk bahan bangunan, kayu bakar dan bahan arang. Bentuk pemanfaatan tersebut tidak hanya dilakukan masyarakat di Telaga Wasti Sowi IV saja, namun umumnya juga dilakukan oleh masyarakat di Rendani, Sowi, Arfai dan Andai Kabupaten Manokwari. 
1. Pemanfaatan Tumbuhan Mangrove Sebagai Bahan Konstruksi Bangunan

Tercatat 3 jenis tumbuhan mangrove yang digunakan oleh warga masyarakat di Telaga Wasti Sowi IV sebagai bahan konstruksi bangunan (Tabel 5).

\section{Pemanfaatan Tumbuhan Mang- rove Sebagai Bahan Kayu Bakar}

Terdapat 6 jenis tumbuhan mangrove yang digunakan sebagai bahan kayu bakar oleh sebagian besar anggota masyarakat di Telaga Wasti Sowi IV (Tabel 6).

\section{Pemanfaatan Tumbuhan Mang- rove Sebagai Bahan Obat-obatan}

Hasil identifikasi tumbuhan mangrove yang dimanfaatkan oleh masyarakat di Telaga Wasti Sowi IV sebagai bahan obat tradisional dijumpai dalam plot pengamatan sebanyak 3 jenis (Tabel 7).
Bagian kulit dari jenis Ceriops tagal digerus kemudian direbus lalu air rebusanya diminum untuk membantu dalam persalinan. Begitu juga jenis Rhizophora mucronata bagian yang dimanfaatkan adalah kulitnya ditumbuk lalu diletakkan pada bagian gigi yang sakit. Jenis lain yang dimanfaatkan oleh beberapa warga masyarakat Telaga Wasti Sowi IV, yaitu biji Xylocarpus moluccensis sebagai obat sakit perut.

Meskipun mangrove disebutkan dapat menjadi bahan obat-obatan dan pangan (Priyono, et al,. 2010; Bengen, 2003), pemanfaatannya di lokasi studi masih sangat rendah. Lebih dari $70 \%$ responden tidak mengetahui bahwa mangrove dapat dimanfaatkan sebagai bahan obat-obatan dan pangan. Hal ini disebabkan belum adanya pengetahuan masyarakat untuk mengolahnya, senada dengan pemaparan Tuwo (2011), yakni bahwa potensi sumberdaya pesisir dan laut belum dimanfaatkan secara optimal oleh masyarakat karena kurangnya pengetahuan.

Tabel 5. Jenis mangrove yang dimanfaatkan sebagai bahan konstruksi bangunan

\begin{tabular}{|c|c|c|c|}
\hline No. & Jenis & $\begin{array}{l}\text { Nama } \\
\text { Lokal }\end{array}$ & Kegunaan \\
\hline 1. & $\begin{array}{l}\text { Rhizophora } \\
\text { apiculata }\end{array}$ & Ampiuw & $\begin{array}{l}\text { Tiang Penyanga (Batang } \\
\text { Pohon) }\end{array}$ \\
\hline 2. & $\begin{array}{l}\text { Rhizophora } \\
\text { mucronata }\end{array}$ & Ampiuw & $\begin{array}{l}\text { Tiang Penyanga (Batang } \\
\text { Pohon) }\end{array}$ \\
\hline 3. & Lumnitzera littorea & Kris & $\begin{array}{l}\text { Tiang Penyanga (Batang } \\
\text { Pohon) }\end{array}$ \\
\hline
\end{tabular}

Sumber: Data primer (2018)

Tabel 6. Jenis mangrove yang dimanfaatkan sebagai bahan kayu bakar

\begin{tabular}{ccll}
\hline No. & \multicolumn{1}{c}{ Jenis } & Nama Lokal & Bagian yang Digunakan \\
\hline 1. & Aegiceras corniculatum & Aibon & $\begin{array}{l}\text { Ranting dan Batang } \\
\text { Pohon } \\
\text { Ranting dan Batang }\end{array}$ \\
2. & Bruguiera gymnorrhiza & Aibon & $\begin{array}{l}\text { Pohon } \\
\text { Ranting dan Batang } \\
\text { Pohon }\end{array}$ \\
3. Ceriops tagal & Manggringgring & $\begin{array}{l}\text { Ranting dan Batang } \\
\text { Pohon }\end{array}$ \\
4. Rhizophora apiculata & Ampiuw &
\end{tabular}




\begin{tabular}{|c|c|c|c|}
\hline 5. & Rhizophora mucronata & Ampiuw & $\begin{array}{l}\text { Ranting dan Batang } \\
\text { Pohon }\end{array}$ \\
\hline 6. & $\begin{array}{l}\text { Xylocarpus } \\
\text { moluccensis }\end{array}$ & Kabau & $\begin{array}{l}\text { Ranting dan Batang } \\
\text { Pohon }\end{array}$ \\
\hline
\end{tabular}

Sumber: Data primer (2018)

Tabel 7. Jenis mengrove yang dimanfaatkan sebagai bahan Obat-obatan

\begin{tabular}{rlll}
\hline No. & \multicolumn{1}{c}{ Jenis } & Nama Lokal & \multicolumn{1}{c}{ Kegunaan } \\
\hline 1. & Ceriops tagal & Manggringgring & $\begin{array}{l}\text { Obat Persalinan } \\
\text { (Kulit) }\end{array}$ \\
2. & $\begin{array}{l}\text { Rhizophora } \\
\text { mucronata }\end{array}$ & Ampiuw & $\begin{array}{l}\text { Obat Sakit Gigi } \\
\text { (Kulit) }\end{array}$ \\
3. $\begin{array}{l}\text { Xylocarpus } \\
\text { moluccensis }\end{array}$ & Kabau & $\begin{array}{l}\text { Obat Sakit Perut } \\
\text { (Biji) }\end{array}$ \\
\hline
\end{tabular}

Sumber: Data primer (2018)

\section{Pemanfaatan Tumbuhan Mangrove Sebagai Sumber Keperluan Lainnya}

Hasil identifikasi tumbuhan mangrove yang dimanfaatkan oleh masyarakat di Telaga Wasti Sowi IV untuk keperluan lainnya, seperti: pangan, bahan pewarna dan alat tarnsportasi seperti perahu dijumpai sebanyak 5 jenis (Tabel 8).

Tabel 8. Jenis mangrove yang dimanfaatkan sebagai sumber bahan keperluan

\begin{tabular}{clll}
\multicolumn{4}{c}{ lainnya } \\
\hline No. & \multicolumn{1}{c}{ Jenis } & \multicolumn{1}{c}{ Nama Lokal } & \multicolumn{1}{c}{ Kegunaan } \\
\hline 1. & Aegiceras corniculatum & Aibon & Racun Ikan (Kulit) \\
2. & Bruguiera gymnorrhiza & Aibon & Pangan (Buah) \\
3. & Ceriops decandra & Manggringgring & Pegangan Perkakas (Kayu) \\
4. & Rhizophora mucronata & Ampiuw & Pewarna (Kulit) \\
5. & Xylocarpus & Kabau & Perahu (Batang Pohon) \\
\hline
\end{tabular}

Sumber: Data primer (2018)

Jenis Bruguiera gymnorrhiza yang dimanfaatkan patinya sebagai sumber karbohidrat oleh beberapa warga masyarakat di Telaga Wasti Sowi IV. Sedangkan jenis Xylocarpus moluccensis dimanfaatkan sebagai bahan pembuatan badan perahu.

\section{PEMBAHASAN}

Telaga Wasti merupakan salah satu lahan basah pesisir berupa tumbuhan mangrove. Nama kawasan ini berasal dari nama leluhur yang memiliki hak ulayat pada kawasan tersebut dan dipadukan dengan sebuah telaga yang berada di antara pepohonan mangrove nan hijau bagaikan permadani. Telaga Wasti juga merupakan salah satu kawasan wisata dengan prospek pengembangan ekoturisme yang cukup potensial selain kawasan Pantai Pasir Putih yang sudah terkenal dan memiliki jumlah pengunjung wisatawan (lokal dan mancanegara) yang tinggi. Telaga Wasti terletak pada posisi $134^{\circ} 3^{\prime} 00$ BT - 0055'30 LS di sebelah Selatan Kabupaten Manokwari dengan jarak tempuh $\pm 12 \mathrm{Km}$ dari Ibukota Kabupaten dan dapat ditempuh dengan jalan darat/kendaraan bermotor dengan waktu tempuh 20 menit. 


\section{Kondisi Vegetasi Hutan Mangrove Di Telaga Wasti Sowi IV}

Hasil analisis data melalui nilai kerapatan maupun penyebaran jenis tumbuhan mangrove yang telah dilakukan menunjukkan bahwa Rhizophora merupakan jenis yang dominan dalam vegetasi hutan mangrove pada lokasi penelitian baik pada vegetasi tingkat pohon, belta dan semai. Hal ini diperkuat oleh pendapat Kustanti (2011), bahwa Rhizophora merupakan salah satu jenis tumbuhan mangrove yang dominan dalam suatu kawasan hutan mangrove.

Melalui analisis nilai kerapatan menunjukkan bahwa vegetasi mangrove pada lokasi studi belum mendapatkan gangguan yang berarti dari masyarakat setempat, walaupun pada beberapa tempat telah mengalami gangguan berupa pembukaan hutan mangrove sebagai lokasi pemukiman tetapi masih dalam sakala yang kecil. Menurut Fachrul (2007) kerapatan dapat digunakan untuk melihat besarnya gangguan terhadap suatu habitat. Jika nilai kerapatan jenis tumbuhan pada suatu habitat rendah/kecil maka pada habitat tersebut telah mengalami kerusakan, sebaliknya jika nilai kerapatan jenis tumbuhan tersebut tinggi/besar maka pada habitat tersebut belum mengalami kerusakan.

Berdasarkan hasil analisis yang telah dilakukan, nilai kerapatan pada lokasi pengamatan berkisar antara 108.33 - 784.66/ha. Nilai tersebut jika dibandingkan dengan Nilai Kriteria Baku Kerusakan Mangrove berdasarkan Kepmeneg LH No. 201 Tahun 2004, maka dapat dikatakan bahwa kondisi vegetasi hutan mangrove di Manokwari terutama pada lokasi penelitian dikategorikan sebagai rusak dan jarang karena berada di bawah nilai 1000 . Hasil ini diperkuat dengan data dari Dinas Kehutanan dan Perkebunan Papua Barat (2011) bahwa 1.995 ha kawasan hutan mangrove di Kabupaten Manokwari mengalami rusak berat, 1.011 ha dalam keadaan rusak ringan dan sisanya 642 ha dalam kondisi baik. Berikut Kriteria Baku Kerusakan Mangrove berdasarkan Kepmeneg LH No. 201 Tahun 2004 (Tabel 9).

Tabel 9. Kriteria baku kerusakan mangrove

\begin{tabular}{llcc}
\hline \multicolumn{2}{c}{ Kriteria } & Penutupan & Kerapatan $($ Pohon/Ha) \\
\hline Baik & Sangat & $>70$ & $>1.500$ \\
& Padat & $>50$ & $>1.000-$ \\
& Sedang & $->70$ & $>1.500$ \\
Rusak & Jarang & $<50$ & $<1.000$ \\
\hline
\end{tabular}

Sumber: Data Kepmeneg LH No. 201 Tahun 2004

Jika dilihat dari penyebaran dan keragaman jenis, maka jenis Rhizophora merupakan jenis yang memiliki penyebaran yang merata, hal ini dikarenakan substrat pada lokasi berupa pasir berkarang dan berlumpur mulai dari garis pantai sampai ke arah daratan menyebabkan jenis-jenis yang tumbuh lebih beragam. Sementara itu perhitungan nilai keanekaragaman jenis
$\left(\mathrm{H}^{\prime}\right)$ di lokasi penelitian menunjukkan bahwa sebaran individu dan keanekaragaman jenis pada daerah tersebut tergolong sedang karena menurut klasifikasi Odum (1971) nilai ideks keanekaragaman antara $1-3$ memiliki nilai keanekaragaman sedang dan indeks keanekaragaman lebih dari tiga merupakan keanekaragaman yang tinggi. Berdasarkan analisis data di atas, 
maka dapat dikatakan bahwa ekosistem mangrove di wilayah ini sudah mulai mendapat tekanan ekologi, karena secara umum keanekaragaman yang tinggi menunjukkan keseimbangan ekosistem yang lebih baik dan memberikan ketahanan yang lebih besar terhadap gangguan, perubahan faktor lingkungan dan lain sebagainya, sedangkan pada daerah tersebut keanekaragamannya tergolong sedang.

\section{Pemanfaatan Hutan Mangrove Oleh Masyarakat Di Telaga Wasti Sowi IV}

Menurut hasil wawancara dengan responden diketahui bahwa aneka ragam hayati hutan mangrove dimanfaatkan penduduk untuk berbagai kegunaan seperti pemanfaatan tumbuhan mangrove sebagai bahan bangunan, sumber kayu bakar dan arang, sumber bahan obat-obatan dan manfaat lainnya seperti: sumber bahan pangan dan pewarna, alat transportasi dan racun.

\section{Pemanfaatan Tumbuhan Mang- rove Sebagai Bahan Konstruksi Bangunan}

Bagi masyarakat yang mendiami wilayah pesisir terutama di sekitar hutan mangrove, hutan mangrove merupakan sumber bahan bangunan bagi mereka. Pemanfaatan kayu sebagai bahan bangunan diperoleh dari hutan mangrove sekitarnya terutama sebagai tiang penyangga rumah, jembatan dan tempat penambatan perahu dan hanya diperlukan pada saat mendirikan serta memperbaiki rumah terutama di Sowi. Dengan demikian kebutuhan kayu untuk bahan bangunan rumah, jembatan maupun tempat penambatan perahu diambil dari hutan terdekat terutama hutan mangrove di sekitar Telaga Wasti.

$\begin{array}{llr}\text { Untuk } & \begin{array}{l}\text { keperluan } \\ \text { tiang } \\ \text { penopang }\end{array}\end{array}$

memanfaatkan kayu dari hutan mangrove, seperti: Ampiuw (Rhizophora apiculata dan $R$. mucronata) serta Kris (Lumnitzera littorea). Ketiga jenis ini dianggap memiliki sifat kuat dan tahan air. Jenis Kris (Lumnitzera littorea) juga dimanfaatkan sebagi papan pengalas lantai. Pemanfaatan pohon mangrove sebagai bahan bangunan oleh masyarakat dilakukan secara selektif dimana pengambilannya dilakukan hanya pada saat mendirikan atau pun memperbaiki rumah dan jembatan sehingga tidak mengancam keberadaan jenis-jenis tersebut.

\section{Pemanfaatan Tumbuhan Mang- rove Sebagai Bahan Kayu Bakar}

Sebagian besar anggota masyarakat menggunakan kayu pohon mangrove sebagai sumber energi untuk kebutuhan memasak diperoleh dengan mudah dari hutan mangrove di sekitarnya. Pemanfaatan jenis-jenis pohon mangrove sebagai bahan kayu bakar didasarkan atas pengetahuan mereka tentang jenis-jenis tersebut. Berdasarkan pengalaman berinteraksi dengan hutan mangrove secara turun temurun, mereka mengetahui jenis mana yang baik untuk dijadikan sebagai bahan kayu bakar. Hampir semua jenis pohon mangrove dapat dimanfaatkan sebagai kayu bakar, namun menurut pengetahuan masyarakat bahwa jenis Aibon (Aegiceras corniculatum dan Bruguiera gymnorrhiza), Manggringgring (Ceriops tagal), Ampiuw (Rhizophora apiculata dan $R$. mucronata), dan Kabau (Xylocarpus moluccensis) memiliki bentuk pohon yang lurus dan kuat serta walaupun dalam keadaan basah dapat menghasilkan bara api sehingga memiliki kualitas kayu yang baik untuk dijadikan sebagai kayu bakar. 
Proses pengambilan kayu bakar adalah dengan mengumpulkan ranting dan batang kayu mangrove yang telah tumbang atau menebang langsung pohon kayu, kemudian dipotong sesuai dengan ukuran yang diinginkan. Volume pengambilan kayu bakar tergantung dari besar kecilnya jumlah anggota keluarga dalam satu rumah tangga, karena semakin banyak anggota keluarga maka semakin banyak pula pohon mangrove yang dibutuhkan sebagai kayu bakar.

\section{Pemanfaatan Tumbuhan Mang- rove Sebagai Bahan Obat-obatan}

Pengolahan tumbuhan mangrove sebagai obat oleh masyarakat di Telaga Wasti Sowi IV adalah direbus, kemudian air rebusannya diminum untuk menyembuhkan penyakit yang sedang dialami. Beberapa tumbuhan mangrove yang dimanfaatkan untuk obat antara lain: Manggringgring (Ceriops tagal) air rebusan kulit pohonnya diminum sebagai obat persalinan, Ampiuw (Rhizophora apiculata) kulit pohonnya ditumbuk halus diletakkan pada bagian gigi yang sakit dan Kabau (Xylcarpus moluccensis) air rebusan bijinya diminum sebagai obat sakit perut.

Ada beberapa jenis tumbuhan mangrove lainnya yang walaupun tidak ditemukan dalam plot pengamatan, tetapi berdasarkan hasil wawancara dapat dimanfaatkan sebagai obat tardisional antara lain: Kabisasu (Acanthus illicifolius) air rebusan daunnya diminum sebagai obat rematik. Anas (Camptostemon schultzii) daunnya dipanaskan pada barah api kemudian dipakai untuk menekan ke bagian badan yang sakit seperti memar, keseleo ataupun pegal-pegal, Mares (Heritiera littoralis) getah daunnya dicampur dengan air kemudian dipakai untuk mencuci muka sebagai obat sakit mata (mata merah).

\section{Pemanfaatan Tumbuhan Mang- rove sebagai Sumber Keperluan Lainnya}

Pemanfaatan tumbuhan mangrove untuk keperluan lainnya antara lain: sebagai bahan racun ikan, pangan, pegangan perkakas, pewarna dan alat tarsportasi. Sebagai racun ikan digunakan kulit Aibon (Aegiceras corniculatum), hasil tumbukan kulit tersebut dicampur dengan pakan umpan ikan. Aibon (Bruguiera gymnorrhiza) adalah jenis yang dimanfaatkan untuk bahan pangan dengan memanfaatkan patinya sebagai sumber karbohidrat. Sedangkan kayu jenis Manggringgring (Ceriops tagal) dimanfaatkan oleh masyarakat sebagai pegangan perkakas dan jenis Ampiuw (Rhizophora mucronata) digunakan sebagai bahan pewarna untuk jaring ikan terutama yang bahannya terbuat dari benang. Batang pohon Kabau (Xylcarpus moluccensis) yang memiliki diameter batang lebih dari 100 dijadikan sebagai perahu yang digunakan untuk alat tarnsportasi antara kampung, juga digunakan oleh para nelayan untuk melaut di sekitar perairan Telaga Wasti Sowi IV.

\section{Analisis Perubahan Tutup Lahan Hutan Mangrove}

Untuk mengetahui seberapa besar hutan mangrove yang hilang dari pesisir Distrik Manokwari Selatan terutama pada Telaga Wasti Sowi IV dilakukan analisis terhadap tutupan lahan mangrove.

Melalui cara tersebut diperoleh peta hasil interpretasi guna lahan yang menunjukan adanya perubahan yang cukup signifikan, seperti pada Gambar 3 sampai dengan 7 . 


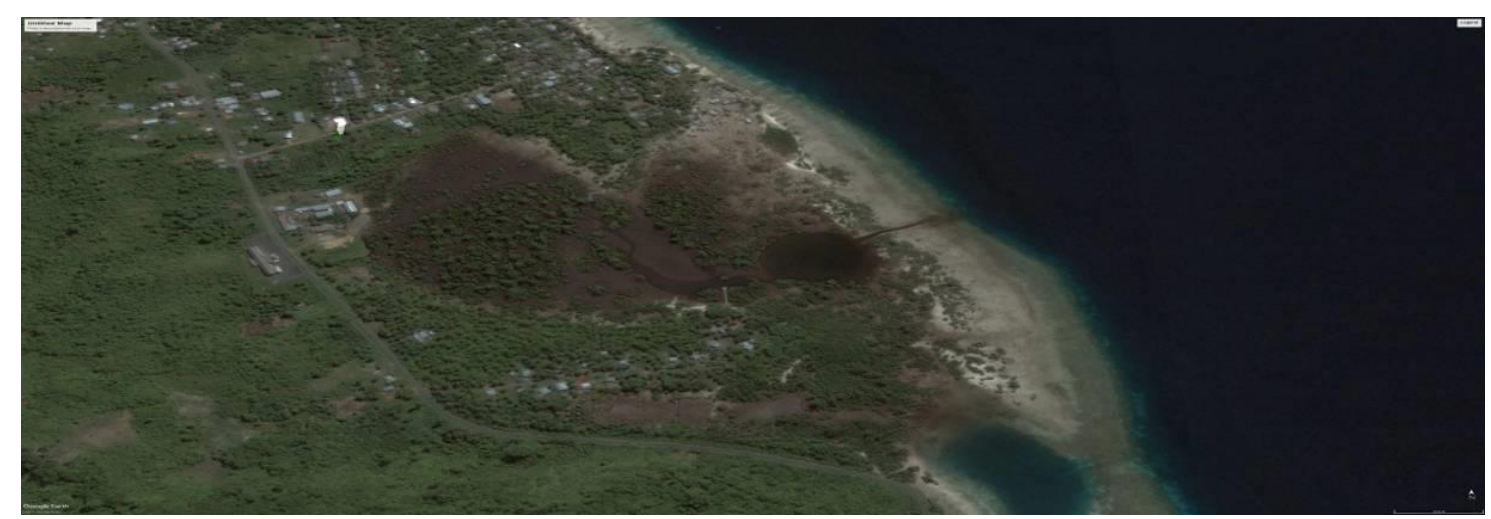

Gambar .3. Peta tutupan hutan mangrove Telaga Wasti tahun 2006 Sumber: Diolah penulis dari Citra Landsat (2018)

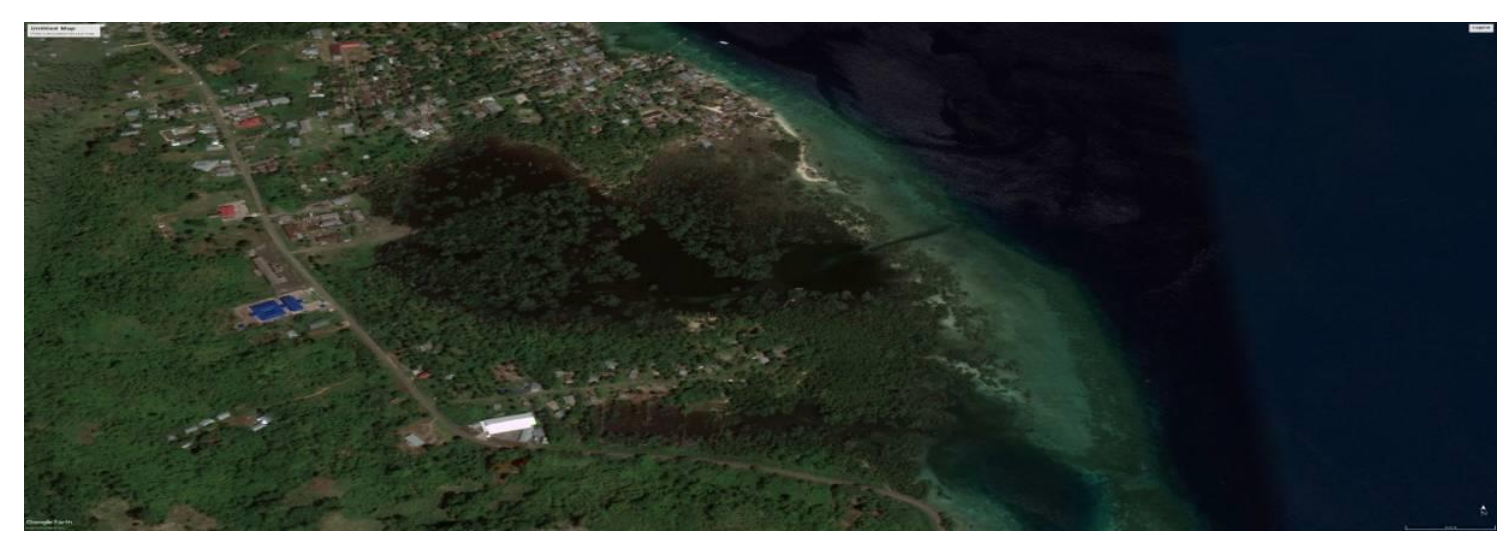

Gambar. 4. Peta tutupan hutan mangrove Telaga Wasti tahun 2010 Sumber: Diolah penulis dari Citra Landsat (2018)

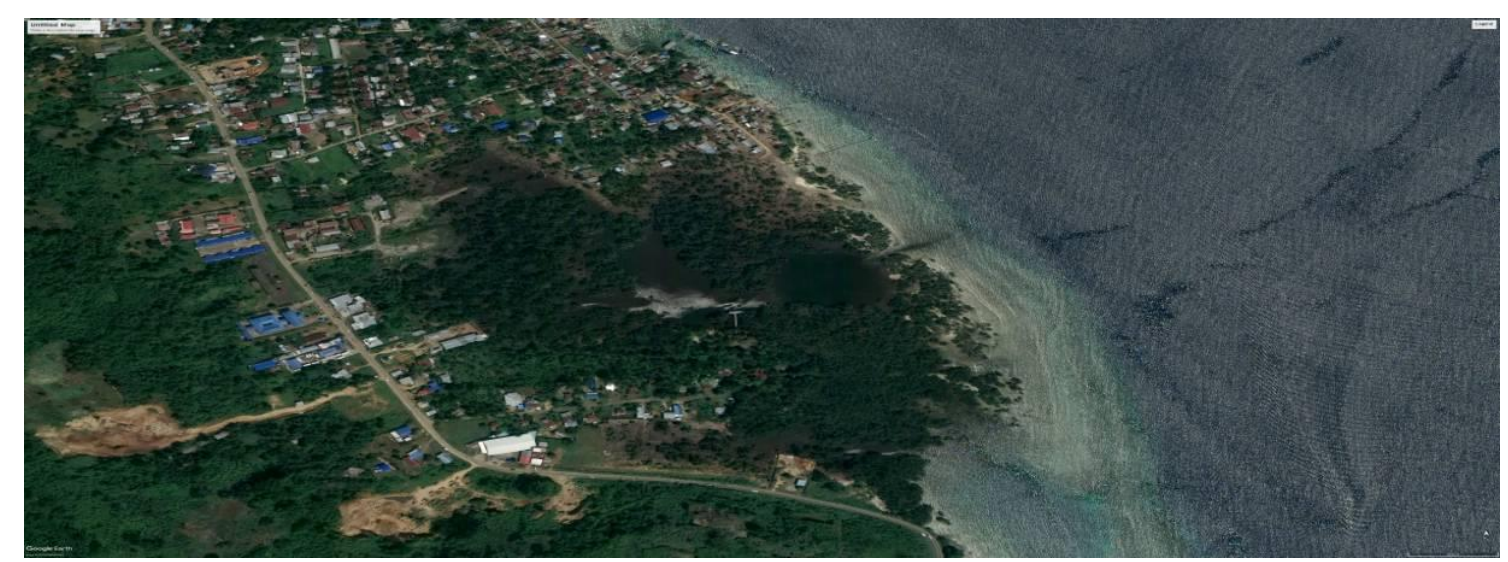

Gambar .5. Peta tutupan hutan mangrove Telaga Wasti tahun 2015 Sumber: Diolah penulis dari Citra Landsat (2018) 


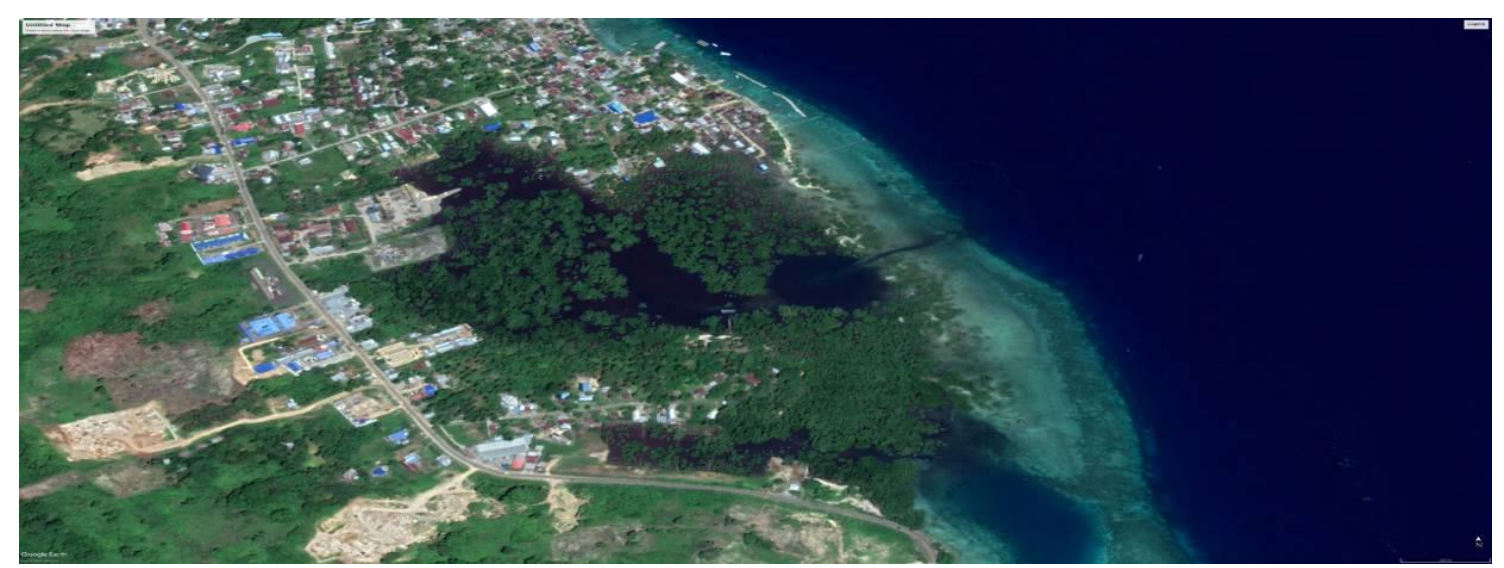

Gambar 6. Peta tutupan hutan mangrove Telaga Wasti tahun 2017

Sumber: Diolah penulis dari Citra Landsat (2018)

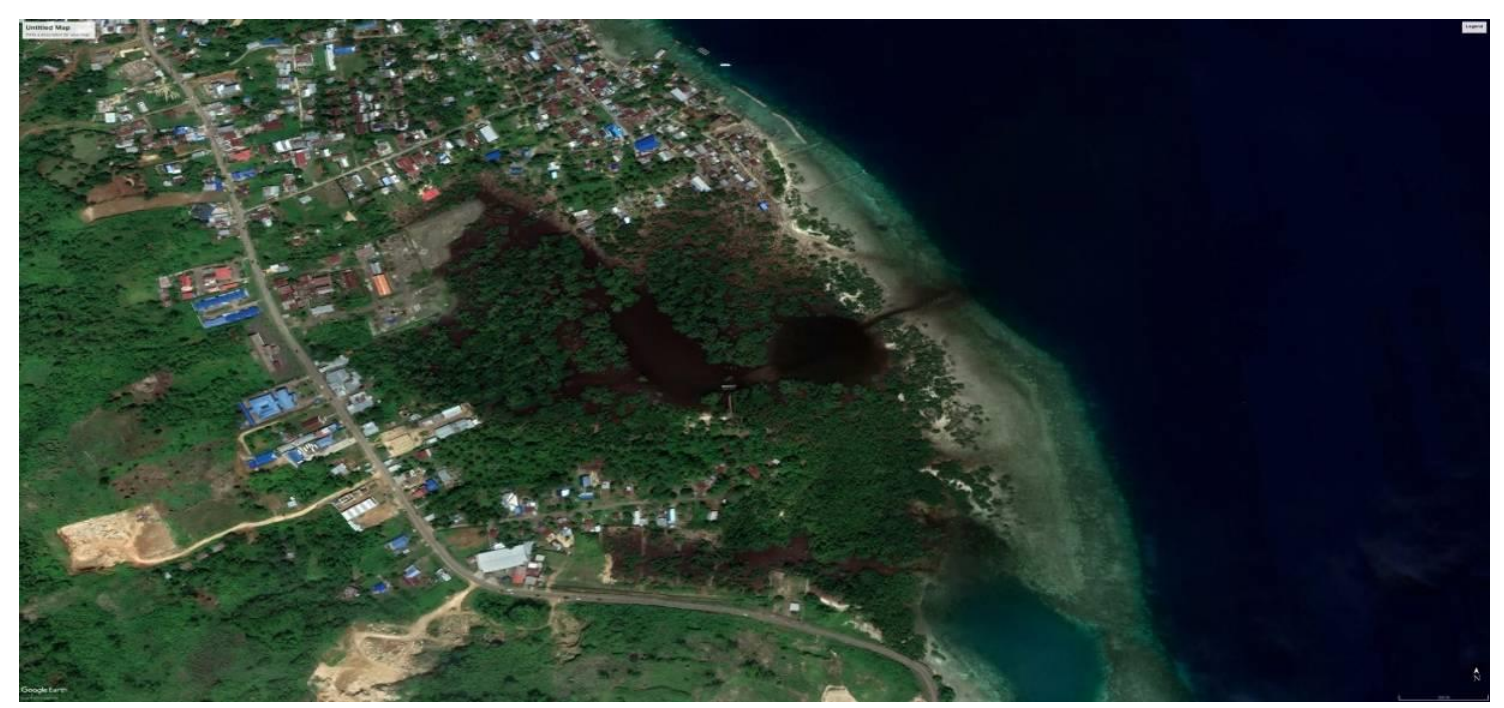

Gambar 7. Peta tutupan hutan mangrove elaga Wasti Sowi IV tahun 2018

Sumber: Diolah penulis dari Citra Landsat (2018)

Dari hasil interpretasi citra dan pemetaan tersebut tampak jelas bahwa hutan mangrove semakin menurun arealnya. Pada tahun 2006 hutan mangrove masih tampak hijau di pesisir dan di dalam Telaga Wasti Sowi IV, kemudian tahun 2010 beberapa bagian sudah menjadi warna merah yang menandakan adanya alih fungsi hutan mangrove menjadi permukiman dan perkebunan.

Dengan melihat luasan dari SIG diperoleh data yang di komparasikan dengan data statistik bahwa luasan hutan mangrove memang mengalami penurunan seperti pada Tabel 10 sedangkan luas permukiman bertambah seperti pada Tabel 11.

Tabel 10. Luas hutan mangrove di Telaga Wasti Sowi IV

\begin{tabular}{cccc}
\hline No. & Tahun & $\begin{array}{c}\text { Luasan Hutan Mangrove } \\
\text { (ha) }\end{array}$ & $\begin{array}{c}\text { Perubahan } \\
(\%)\end{array}$ \\
\hline 1. & 2006 & 26,5 & 15 \\
2. & 2010 & 23,3 & 10 \\
3. & 2013 & 22 &
\end{tabular}


4. 2015 21

5. 2018 19,03 5

Sumber: Analisis penulis (2018)

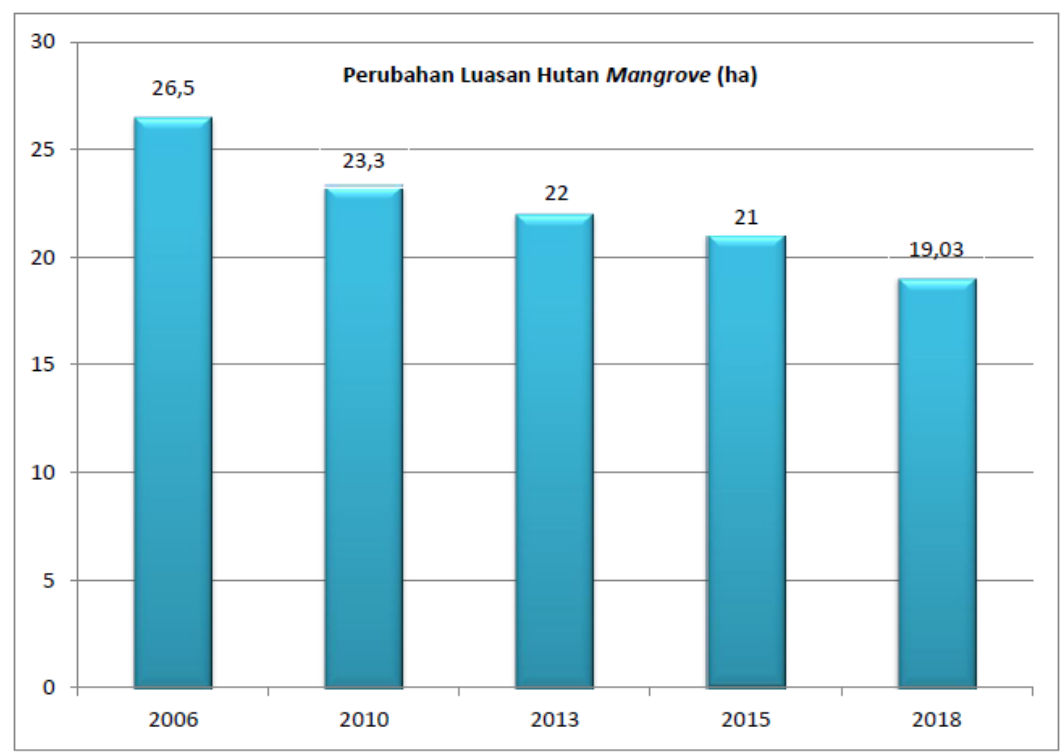

Gambar 8. Grafik perubahan luasan hutan mangrove (ha) di Telaga Wasti Sowi IV Sumber: Analisis penulis (2018)

Tabel 11. Luas permukiman di Telaga Wasti Sowi IV

\begin{tabular}{cccc}
\hline No. & Tahun & Luasan Hutan Mangrove (ha) & Perubahan (\%) \\
\hline 1. & 2006 & 1 & 2 \\
2. & 2013 & 3,2 & 1 \\
3. & 2018 & 4,64 & \\
\hline
\end{tabular}

Sumber: Analisis penulis (2018)

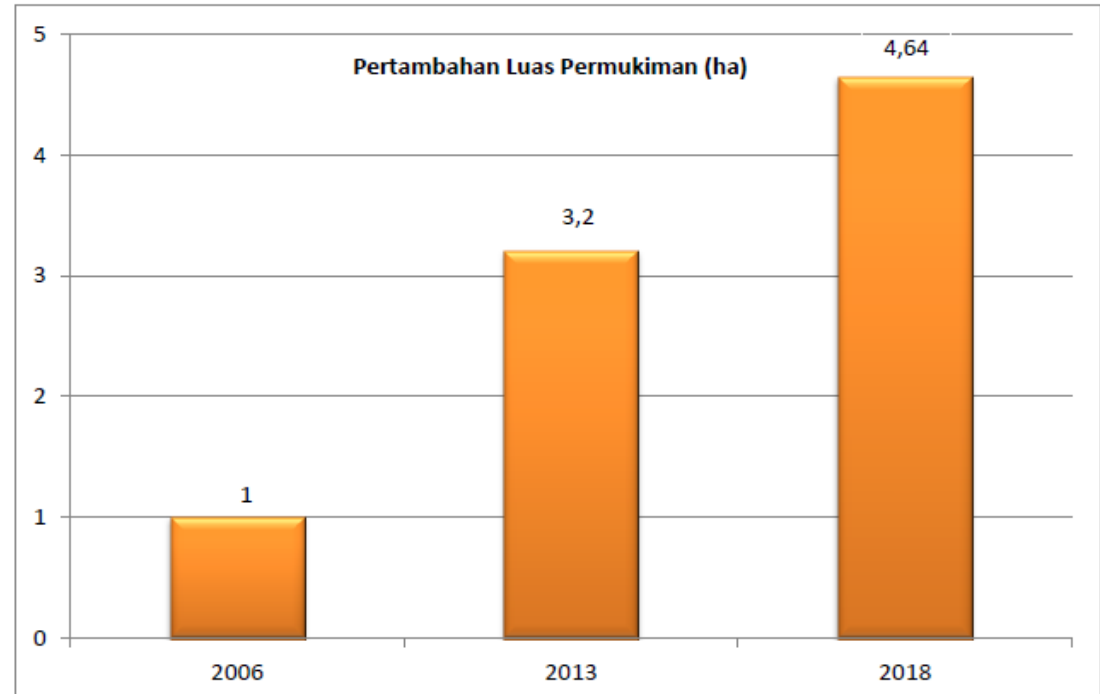

Gambar 9. Grafik perubahan luasan permukiman di Telaga Wasti Sowi IV

Sumber: Analisis penulis (2018) 
Dari perolehan tersebut dapat disimpulkan bahwa luasan hutan mangrove tiap tahun mengalami penurunan sedangkan indikasi adanya alih fungsi hutan mangrove ditunjukan dengan adanya luasan permukiman dan industri mebel yang semakin bertambah serta bertambah pula perkebunan dan peternakan babi.

\section{Analisis Permasalahan}

Dari analisis tutupan hutan mangrove diperoleh permasalahan berkurangnya luasan hutan mangrove yang selanjutnya dianalisis dengan melakukan observasi langsung di lapangan sehingga diperoleh beberapa gambaran di lapangan tentang penyebab hilangnya areal mangrove seperti pada Gambar 10 yang menunjukan beberapa kondisi pesisir Telaga Wasti Sowi IV.

Melihat hasil dari observasi di lapangan diketahui beberapa penyebab berkurangnya hutan mangrove pada pesisir Distrik Manokwari Selatan khususnya di Telaga Wasti Sowi IV, antara lain:
1. Alih fungsi hutan mangrove ke permukiman secara besar-besaran sebesar $4 \%$

2. Alih fungsi hutan mangrove ke perkebunan yang dirasa penduduk lebih menguntungkan seperti tanaman holtikultur

3. Hempasan gelombang yang merusak hutan mangrove

4. Penebangan liar untuk kepentingan penduduk sekitar

Dari hasil analisis ini beberapa penyebab telah diketahui sehingga dapat disusun langkah-langkah strategis dalam pengelolaan dan pemanfaatan hutan mangrove yang berkelanjutan

Dari beberapa permasalahan penyimpangan yang telah teridentifikasi maka diperlukan sebuah strategi pengelolaan hutan mangrove antara lain pengaturan terhadap alih fungsi areal mangrove, pengendalian pemanfaatan ruang dan sumberdaya dan upaya pelestarian hutan mangrove yang berkelanjutan.
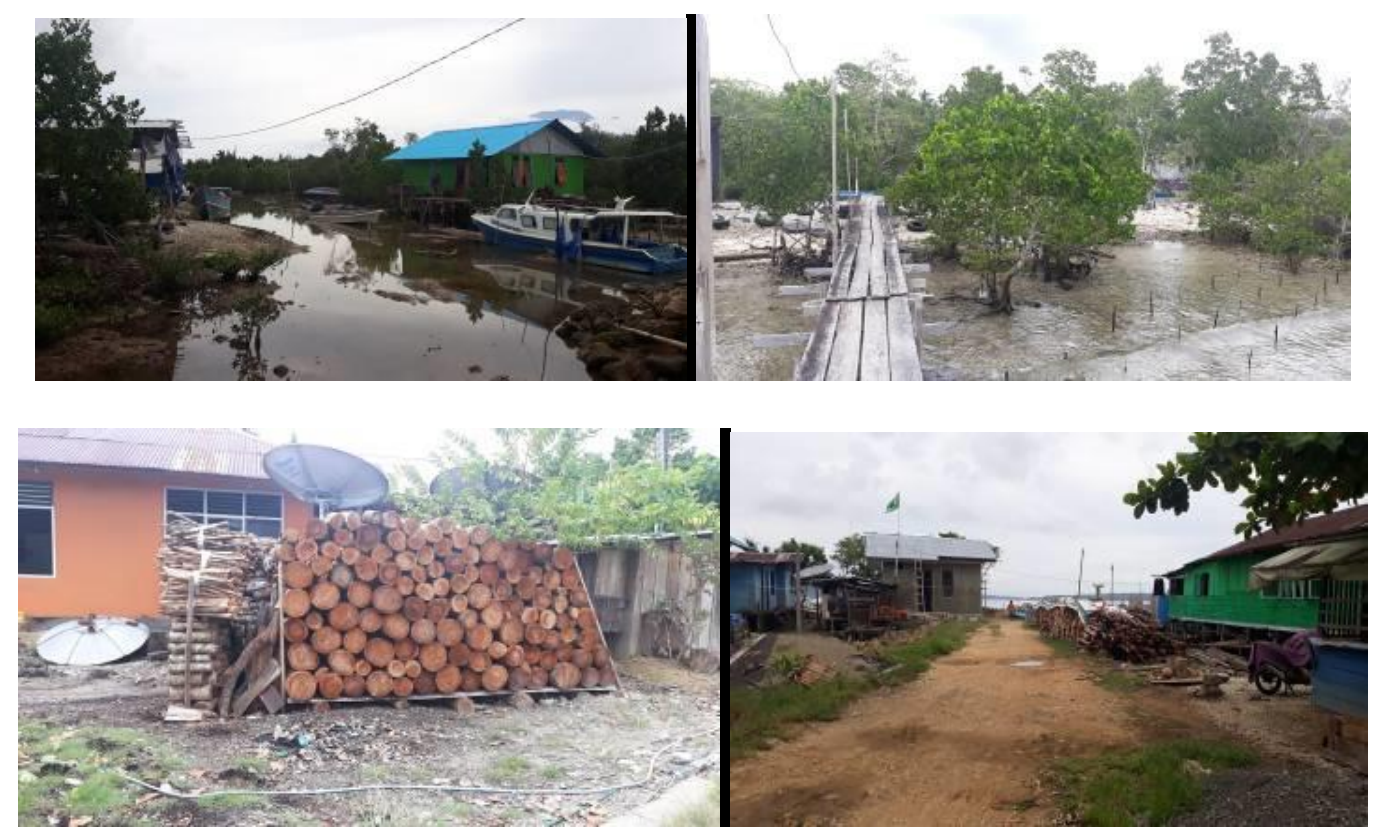

Gambar 10. Kondisi lapangan penyebab hilangnya hutan mangrove Sumber: Survei primer penulis (2018) 


\section{KESIMPULAN}

Kesimpulan dari hasil penelitian ini antara lain:

1. Bahwa pada lokasi penelitian/plot pengamatan ditemukan sebanyak 8 jenis tumbuhan mangrove dari 4 famili, keanekaragaman hayati tumbuhan mangrove pada lokasi penelitian tergolong sedang karena memiliki nilai indeks keanekaragaman $\left(\mathrm{H}^{\prime}\right)<3$, yaitu 1.25 dan pemanfaatan keanekaragaman tumbuhan mangrove di lokasi penelitian antara lain sebagai bahan bangunan 3 jenis, sebagai bahan kayu bakar 6 jenis, sebagai bahan obat-obatan 3 jenis dan 5 jenis sebagai sumber keperluan lainnya.

2. Sebanyak $70 \%$ masyarakat mengaku mengenal hutan mangrove di lokasi penelitian dan mengatakan kondisi hutan mangrove kurang baik maka perlu dilakukannya rehabilitasi.

3. Hal yang perlu dilakukan masyarakat di lokasi penelitian untuk pengelolaan hutan mangrove yang berkelanjutan adalah dengan pelestarian lingkungan hidup dan untuk memastikan kondisi hutan mangrove tidak semakin rusak perlu adanya kebijakan hukum dari pemerintah.

\section{SARAN}

Perlu dilakukannya penelitian lebih lanjut tentang dampak kerusakan mangrove terhadap sosial ekonomi masyarakat di Telaga Wasti Sowi IV sehingga dapat diketahui manfaat ekosistem pesisir terhadap sosial maupun ekonomi masyarakat. Adanya peran pemeritah dalam menjaga kondisi ekosistem mangrove dan lingkungan Telaga Wasti Sowi IV dari masyarakat khususnya dan juga perlu kesadaran setiap pengunjung agar turut menjaga kelestarian dan keberlanjutannya.

\section{DAFTAR PUSTAKA}

Anugra F, Husain U, dan Bau T. 2014. Tingkat Kerusakan Hutan

Mangrove Pantai di Desa

Malakosa Kecamatan Balinggi

Kabupaten Parigi Moutong.

Warta Rimba 2 (1): 54-61.

Arief A. 2003. Hutan Mangrove, Fungsi dan Manfaatnya. Kanisius: Yogyakarta.

Bengen DG. 2004. Ekosistem dan Sumber Daya Alam Pesisir dan Laut Serta Prinsip Pengelolaannya. Sinopsis. PKSPL. IPB: Bogor.

Dahuri R, Rais, J, Ginting SP, Sitepu MJ. 2004. Pengelolaan Sumber Daya Wilayah Pesisir dan Lautan Secara Terpadu. Cetakan III, Edisi Revisi 2004. Paramita: Jakarta.

Dinas Kehutanan Provinsi Papua Barat. 2011. Informasi Hutan Papua Barat.

http://dishut.papuabaratprov.go.id. Diakses tanggal, 15 Mei 2018.

Efriyeldi dan Zulkifli. 2012. Kelimpahan Dan Nisbah Kelamin Siput Bakau (Telescopium telescopium) Di Ekosistem Mangrove Desa Darul Aman Kecamatan Rupat Kabupaten Bengkalis. Jurnal Perikananan dan Kelautan 20 (1): 24-31.

Fachrul MF. 2007. Metode Sampling Bioekologi. Bumi Aksara: Jakarta.

Kaswadji R. 2001. Keterkaitan Ekosistem Di Dalam Wilayah 
Pesisir. Fakultas Perikanan dan Kelautan. IPB: Bogor.

Keputusan Menteri Negara Lingkungan Hidup (Kepmeneg LH) Nomor 201 Tahun 2004 Tentang Kriteria Baku dan Pedoman Penentuan Kerusakan Mangrove.

Kordi K. 2012. Ekosistem Mangrove, Potensi, Fungsi Dan Pengelolaan. Rineka Cipta: Jakarta.

Krebs CJ. 1989. Ecological Methodology. Harper \& Row Inc: New York.

Kusmana C. 2002. Pengelolaan Ekosistem Mangrove Secara Berkelanjutan dan Berbasis Masyarakat. Lokakarya Nasional Pengelolaan Ekosistem Mangrove. Jakarta, 6-7 Agustus 2002.

Kustanti A. 2011. Manajemen Hutan Mangrove. IPB Press: Bogor.

Matan OPM, Djoko $\mathrm{M}$ dan $\mathrm{Su}$ Ritohardoyo. 2010. Keanekaragaman Dan Pola Komunitas Hutan Mangrove Di Andai Kabupaten Manokwari. Majalah Geografi Indonesia 24 (1): 36-53.

Noor YK, Khaali M dan Suryadiputra INN. 2006. Panduan Pengenalan Mangrove Di Indonesia. PHKA/ WI-IP: Bogor.

Nontji, A. 2002. Laut Nusantara. Djambatan: Jakarta.

Odum, 1971. Fundamentals of Ecology. Sounders: Toronto.

Okoseray KM, Nurhani W dan Dedi P. 2017. Pemanfaatan, Persepsi Dan
Partisipasi Masyarakat Terhadap Pelestarian Ekosistem Pesisir Di Distrik Manokwari Selatan. Jurnal Sumberdaya Akuatik Indopasifik 1 (1): 93-104.

Saparinto C. 2007. Pendayagunaan Ekosistem Mangrove. Dahara Prize: Semarang.

Supriharyono. 2007. Konservasi Ekosistem Sumber Daya Hayati Di Wilayah Pesisir Dan Laut Tropis. Pustaka Belajar: Yogyakarta.

Toknok B. 2012. Restorasi Ekosistem Mangrove Tanjung Malakosa Di Kabupaten Parigi Moutong Sulawesi Tengah. [Disertasi]. Universitas Mulawarman, Samarinda. [Tidak Dipublikasi-kan].

Tuwo A. 2011. Pengelolaan Ekowisata Pesisir Dan Laut. Brilian Internasional: Surabaya.

Warpur M. 2016. Struktur Vegetasi Hutan Mangrove dan Pemanfaatannya di Kampung Ababiaidi Distrik Supiori Selatan Kabupaten Supiori. Jurnal Biodjati 1 (1): 19-26. 